\section{Variability in Seed Characteristics of Unselected and Selected Jojoba Populations}

\author{
Himayat H. Naqvi, Mitsuo Matsumura, and Irwin P. Ting \\ Department of Botany and Plant Sciences, University of California, \\ Riverside, CA 92521
}

Additional index words. liquid wax, industrial crops, lubricants, cosmetics

Jojoba, Simmondsia chinensis (Link) Schneider, a perennial evergreen shrub native to the Sonoran Desert in North America, is being developed as an industrial crop for semi-arid environments. Most of the 16,000 ha of the existing jojoba plantations were established by seed harvested from wild jojoba populations (Naqvi et al., 1988a). Because jojoba is easily propagated vegetatively, one can control the ratio of male and female plants in the field and bring about a high degree of plant uniformity for farm mechanization. For a successful cloning program, genetically superior plants need to be continuously available.

Yermanos and his associates made extensive investigations of jojoba seeds collected from wild populations in Arizona, Califorma, and Mexico (Clark and Yermanos, 1980; Yermanos and Duncan, 1976) and found significant variability in seed production, seed size and weight, and wax content per seed. They concluded that selection for large seed size and high oil content may be important for developing high-yielding jojoba cultivars. Selection and other agronomic studies are currently in progress at the Univ. of California, Riverside (Naqvi et al., 1988b).

The objective of this investigation was to evaluate yield and seed characteristics of two jojoba populations that were derived from a base population raised from seed collected in nine different locations in California and

Received for publication 3 Apr. 1989. Contribution of the College of Natural and Agricultural Sciences, and the Department of Botany and Plant Sciences, Univ. of California, Riverside. The cost of publishing this paper was defrayed in part by the payment of page charges. Under postal regulations, this paper therefore must be hereby marked advertisement solely to indicate this fact.
Arizona. An unselected population was established from random samples of seeds from each of the nine collection locations and was replicated six times. The selected population included 42 entries in three replications. The 42 entries (selections) were raised from seeds selected from the base population for large seed size $(>0.90 \mathrm{~g} / \mathrm{seed})$ and high oil content $(>0.45 \mathrm{~g} / \mathrm{seed})$. Both populations were established by Yermanos in May 1979.

In Summer 1988, mature seeds were handcollected from 44 and 82 plants chosen at random in the unselected and selected populations, respectively. Seeds were air-dried for $72 \mathrm{hr}$ at $\approx 50 \mathrm{C}$, weighed, and yield per tree was determined. Ten seeds were randomly picked from each lot (plant) and measured for seed weight, length, and width. For wax determination, a wide line Mark III NMR analyzer (Newport Instruments, Villanova, Pa.) was used. Seeds were dried further and $18 \mathrm{~g}$ were used in a 40-ml NMR tube for each analysis. Character means were calculated and differences between population means were tested using Student's unpaired $t$ test. Correlation coefficients were determined for selected pairs of characteristics.

Seeds in the selected population have higher values in almost all the traits investigated (Table 1). The increase was greatest in seed weight $(21 \%)$ and oil content per seed $(22 \%)$, the two traits that were taken into consideration while choosing seed for the selected population. These higher values were also reflected in the increase in mean total yield per tree $(49 \%)$. The total yield distribution range in the unselected population was between 500 to $3000 \mathrm{~g} /$ tree, while in the selected population, it varied from 1000 to 4500 $\mathrm{g} / \mathrm{tree}$, with a net mean increase of $834 \mathrm{~g} /$ tree. These data reveal that we can make significant advances in yield and other seed characteristics if we use carefully selected seed for establishing new jojoba plantations. Seed weight was positively and significantly correlated with seed length and seed width (Table 2) in both populations. Correlation between seed weight and seed wax content is significant in the unselected population, but not so in the selected population. Per plant yield is positively correlated with seed weight $(P=0.05)$ and seed width $(P=$ 0.05 ) in the unselected population.

Selection of female plants obviously can result in improvement of certain seed characteristics, despite open pollination of the fields.

\section{Literature Cited}

Clarke, J.A. and D.M. Yermanos. 1980. JojobaVariability in oil content and composition in a collection of 1156 native plants. J. Amer. Oil Chem. Soc. 57(6):176-178.

Naqvi. H.H., G. Goldstein, and I.P. Ting. 1988a. Jojoba: A new multipurpose industrial crop for arid environments. El Guaynlero 17(1,2):8-14.

Naqvi, H.H., G. Goldstein, C. Ratnayake, T. Ceceardi, and I.P. Ting. 1988b. Jojoba breeding and agronomic investigations at UC Riverside, p. 393-409. In: A.R. Baldwin (ed.). Proc. 7th Intl. Conf. on Jojoba and its Uses, Phoenix, Aria., 17-22 Jan. 1988. Amer. Oil Chem. Soc., Champaign, III.

Yermanos, D.M. and C.C. Duncan. 1976. Quantitative and qualitative characteristics of jojoba seed. J. Amer. Oil Chem. Soc. 53(2):80-82.

Table 2. Correlation coefficients between various seed characteristics in an unselected and a selected jojoba population.

\begin{tabular}{|c|c|c|}
\hline Trait pairs & $\begin{array}{l}\text { Unselected } \\
\text { population } \\
(\mathrm{N}=44)\end{array}$ & $\begin{array}{c}\text { Selected } \\
\text { population } \\
(\mathrm{N}=82) \\
\end{array}$ \\
\hline $\begin{array}{l}\text { Weight }(\mathrm{g}) \text { vs. } \\
\text { length }(\mathrm{mm}) / \text { seed }\end{array}$ & $0.420^{* *}$ & $0.594^{* *}$ \\
\hline $\begin{array}{l}\text { Weight }(\mathrm{g}) \text { vs. } \\
\text { width }(\mathrm{mm}) / \text { seed }\end{array}$ & $0.878^{* *}$ & $0.832 * *$ \\
\hline $\begin{array}{l}\text { Weight (g) vs. } \\
\text { oil }(\mathrm{g}) / \text { seed }\end{array}$ & $0.308^{*}$ & $0.097^{\mathrm{NS}}$ \\
\hline $\begin{array}{l}\text { Oil (g) vs. } \\
\text { length }(\mathrm{mm}) / \text { seed }\end{array}$ & $0.035^{\mathrm{NS}}$ & $-0.075^{\mathrm{NS}}$ \\
\hline $\begin{array}{l}\text { Oil }(\mathrm{g}) \text { vs. } \\
\text { width }(\mathrm{mm}) / \text { seed }\end{array}$ & $0.282^{\mathrm{NS}}$ & $0.140^{\mathrm{NS}}$ \\
\hline $\begin{array}{l}\text { Yield ( } \mathrm{g} / \text { tree) vs. } \\
\text { length }(\mathrm{mm} / \mathrm{seed})\end{array}$ & $0.163^{\mathrm{NS}}$ & $0.084^{\mathrm{NS}}$ \\
\hline $\begin{array}{l}\text { Yield ( } \mathrm{g} / \text { tree }) \text { vs. } \\
\text { width }(\mathrm{mm} / \mathrm{seed})\end{array}$ & $0.546^{* *}$ & $-0.258^{*}$ \\
\hline $\begin{array}{c}\text { Yield (g/tree) vs. } \\
\text { weight (g/seed) }\end{array}$ & $0.631^{* *}$ & $-0.183^{\mathrm{NS}}$ \\
\hline
\end{tabular}

NS,*,**Nonsignificant or significant at $P=0.05$ or 0.01 , respectively.

Table 1. Means and ranges of various seed characteristics of unselected and selected jojoba populations at the Univ. of California, Riverside. Populations were 9 years old at harvest.

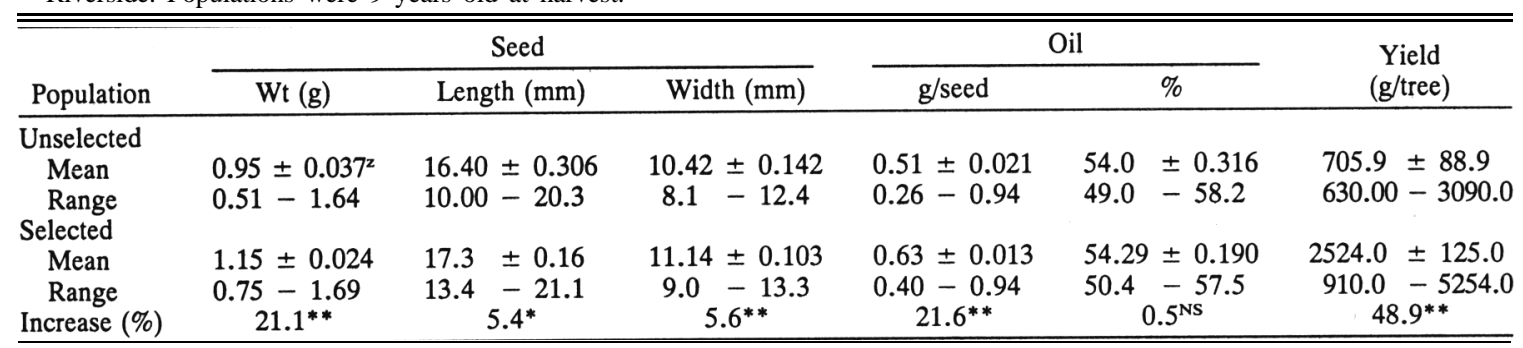

$\mathrm{z}_{ \pm}$Denotes SE

NS, $* * *$ Nonsignificant or significant at $P=0.05$ or 0.01 , respectively. 